\title{
Reducing milking frequency from twice to once daily as an adjunct treatment for ketosis in lactating dairy cows-A randomized controlled trial
}

\author{
M. Williamson, ${ }^{1} \odot$ R. Couto Serrenho, ${ }^{1 *} \odot$ B. W. McBride, ${ }^{2} \odot$ S. J. LeBlanc, ${ }^{1} \oplus$ T. J. DeVries, ${ }^{2} \odot$ \\ and T. F. Duffield ${ }^{1}(1)$ \\ ${ }^{1}$ Population Medicine, University of Guelph, Guelph, ON, Canada N1G 2W1 \\ ${ }^{2}$ Animal Biosciences, University of Guelph, Guelph, ON, Canada N1G 2W1
}

\begin{abstract}
This randomized controlled trial investigated the effects of temporarily reducing milking frequency $(\mathrm{MF})$ on the resolution of ketosis and milk production in dairy cows in early lactation. To detect ketosis [blood $\beta$-hydroxybutyrate (BHB) $\geq 1.2 \mathrm{mmol} / \mathrm{L}]$, Holstein cows were screened daily from 3 to $16 \mathrm{~d}$ in milk using a cow-side meter. Cows diagnosed with ketosis (n $=104)$ were randomly assigned to twice-daily milking (TDM) or reduced to once-daily milking (ODM) for $2 \mathrm{wk}$, then returned to twice-daily milking. Both treatment groups received a 5 -d treatment of an oral propylene glycol drench (PG; $300 \mathrm{~g}$ ) beginning on the afternoon of the diagnosis; cows received additional 5-d PG treatments if they had a ketotic test result (blood $\mathrm{BHB} \geq 1.2 \mathrm{mmol} / \mathrm{L}$ ) at least $4 \mathrm{~d}$ after finishing the first PG treatment. Blood BHB tests were conducted for the first $3 \mathrm{~d}$ after ketosis diagnosis, and then once every 3 $\mathrm{d}$ for $21 \mathrm{~d}$ of trial (DOT). Milk and milk component data were collected weekly for 15 wk following trial enrollment. The ODM group showed rapidly and markedly decreased blood BHB concentrations (primiparous cows: 1 DOT, 0.92 ODM vs. 1.22 TDM, 15 DOT, 0.55 vs. $0.81 \mathrm{mmol} / \mathrm{L}$; multiparous cows: 1 DOT, 1.01 vs. $1.40,15 \mathrm{DOT}, 0.78$ vs. $1.65 \mathrm{mmol} / \mathrm{L})$. In addition, a logistic regression model indicated that ODM cows were less likely to have blood BHB concentrations $\geq 1.2$ mmol/L [primiparous cows: 3 DOT: ODM 1\% (95\% confidence interval: $0-10 \%)$ vs. TDM $43 \%(30-58 \%)$, 15 DOT ODM 0\% (0-0.2\%) vs. TDM 22\% (13-36\%); multiparous cows: 3 DOT: ODM $33 \%(24-44 \%)$ vs. TDM 59\% (48-69\%), 15 DOT ODM 20.9\% (13-31\%) vs. TDM $64 \%(53-74 \%)]$. The proportion of ODM cows that required additional treatments of $\mathrm{PG}$ were substantially lower than the TDM group (ODM: 39\%; TDM: $64 \%$ ) than the TDM cows during the initial 21-d
\end{abstract}

Received March 31, 2021.

Accepted September 7, 2021.

*Corresponding author: rcoutose@uoguelph.ca period. However, during the 2-wk treatment period, cows in the ODM group produced $26 \%$ less milk and $25 \%$ less energy-corrected milk than the TDM cows. During wk 3 to 15 , when all cows were milked twice daily, ODM cows produced less milk $(-14 \%)$ and energy-corrected milk $(-12 \%)$ compared with the TDM group. Milk protein percentage was greater, and milk fat percentage and linear score tended to be greater in the ODM group over $15 \mathrm{wk}$. In conclusion, a 2-wk reduction of MF in ketotic cows from twice to once daily with treatment with PG resolved ketosis and decreased blood BHB concentrations more effectively than treating TDM cows with PG alone. However, the 2-wk MF reduction had immediate and long-term (up to $13 \mathrm{wk}$ after cessation of MF reduction) negative effects on milk production.

Key words: hyperketonemia treatment, once a day milking, energy status, metabolic disease

\section{INTRODUCTION}

Dairy cows in the transition period experience a decrease in DMI, immune and hormonal homeorhetic changes, and a drastic increase in energy demand once lactation begins (Baird, 1982; Herdt, 2000). Failure to adequately adapt to transition challenges can lead to an extended period of negative energy balance (NEB) (Duffield, 2000; Herdt, 2000). Increased production of ketones, to some extent, is an adaptive response to lactation and NEB, but excessive NEB or maladaptive responses can result in hyperketonemia (Herdt, 2000). Hyperketonemia, or ketosis, is defined by a concentration of circulating ketone bodies (typically, BHB $\geq$ $1.2 \mathrm{mmol} / \mathrm{L}$ ) that is associated with increased risk of undesirable outcomes such as increased risk of clinical disease, early culling, reduced milk yield, or decreased reproductive performance (Walsh et al., 2007; Duffield et al., 2009; LeBlanc, 2010; McArt et al., 2012a). It is recommended that ketotic cows receive a $300-\mathrm{g}$ oral drench of propylene glycol (PG) for 3 to $5 \mathrm{~d}$ (McArt et al., 2011, 2012b; Gordon et al., 2013, 2017), which 
resolves approximately 30 to $50 \%$ of cases within $1 \mathrm{wk}$ of diagnosis compared with untreated groups (McArt et al., 2011; Jeong et al., 2018). Cows with hyperketonemia treated daily with a $300-\mathrm{g}$ PG oral drench for $5 \mathrm{~d}$ were 1.5 times more likely to resolve subclinical ketosis (McArt et al., 2011). More recently, Gordon et al. (2017) observed that animals with low blood glucose $(<2.2 \mathrm{mmol} / \mathrm{L})$ given a combination of butaphosphan and cyanocobalamin, as an adjunctive treatment to $\mathrm{PG}$, increased milk production by $3.1 \mathrm{~kg} / \mathrm{d}$. Virtually all research on ketosis treatments have focused on supplementing cows with different forms of carbohydrates (glucose precursors) or with products that may stimulate gluconeogenesis (Gordon et al., 2013). Mann et al. (2017) assessed the effect of 4 treatments protocols including using i.v. glucose in ketotic cows (blood BHB $\geq 1.2 \mathrm{mmol} / \mathrm{L} ; \mathrm{n}=34$ multiparous cows). Although the authors observed decreases in BHB, nonesterified fatty acid (NEFA), and glucagon concentrations by administering glucose i.v., health and production benefits were not observed in a larger clinical trial $(\mathrm{n}=1,249$ cows) of adding i.v. dextrose to oral PG (Capel et al., 2021).

Reducing milking frequency (MF) in dairy cattle has been researched since the early 1960s (Stelwagen et al., 2013). Once-daily milked (1× milking) cows are reported to have 30 to $55 \%$ lower plasma NEFA and BHB concentrations, and greater plasma glucose compared with twice-daily milked $(2 \times$ milking) cows in early lactation (Loiselle et al., 2009; Schlamberger et al., 2010; Phyn et al., 2014). Compared with cows that maintained a $2 \times$ milking schedule, plasma $\mathrm{BHB}$ and NEFA concentrations remained lower in $1 \times$ milking cows 1 to 2 wk after returning to a $2 \times$ milking schedule (Loiselle et al., 2009; Schlamberger et al., 2010; Phyn et al., 2014).

Regardless of the duration of $1 \times$ milking, an immediate decrease in milk yield is a consistent outcome (Davis et al., 1999; Stelwagen et al., 2013). Reported short-term milk yield losses during $1 \times$ milking in early lactation range from 13 to $40 \%$ (Stelwagen et al., 2013). There is also a risk for long-term milk yield loss from periods of short-term reduction in MF (Stelwagen et al., 2013). Considering that milk yield and ECM yield losses range from 0 to $16 \%$ in short-term, early lactation studies (Loiselle et al., 2009; Schlamberger et al., 2010; Phyn et al., 2014), the duration of MF to $1 \times$ milking that minimizes the negative carryover effect on milk production requires further examination. Although improved metabolism and metabolic health were demonstrated after reducing MF in these studies, to our knowledge, no experiments have assessed reduction of MF as a treatment for ketosis. Because ketosis is caused by poor adaptation to an imbalance of energy input and output, a temporary reduction in energy demand could reduce the metabolic challenge and more effectively resolve ketosis.

Our objective was to measure the effect of reducing MF (from $2 \times$ to $1 \times$ milking for a 2 -wk period) in conjunction with oral PG treatment in ketotic dairy cows. Our null hypothesis stated that by reducing MF (in addition to PG treatment) of ketotic cows, blood BHB concentrations and recovery time would not be different than when treating ketosis with PG alone.

\section{MATERIALS AND METHODS}

This work is reported using the REFLECT Guideline (Sargeant et al., 2010). The research methods and study protocol were approved by the University of Guelph Animal Care Committee (AUP\#3617).

\section{Study Population and Farm Management}

Early lactation Holstein cows at the Ontario Dairy Research Centre, University of Guelph, were used for this randomized controlled trial. From November 2016 to September 2017, postpartum primiparous and multiparous cows were enrolled in this study.

In the days before calving, cows were moved from a freestall dry pen to individual box stalls. After calving, cows remained in their box stall and were milked with a portable milking system via a pipeline. When deemed sufficiently healthy to leave the box stall (4 to $6 \mathrm{~d}$ ), cows entered a 2-row freestall pen with an automated milking system (AMS; DeLaval VMS equipped with Herd Navigator).

In the box stalls, cows were fed a TMR once daily, between 0800 and $1000 \mathrm{~h}$, with daily feed intakes measured manually. In the AMS pen, cows consumed a partial mixed ration (PMR) from Insentec feed bins. The PMR was fed once daily between 0900 and 1100 h. Cows in the AMS pen also received grain pellets from the AMS during milkings; pellets were dispensed with head movement (head down into the feed trough) until maximum allowance was reached. The maximum amount of pellets delivered per milking was adjusted in the AMS settings according to treatment group assigned to each cow. During the MF reduction period [first $14 \mathrm{~d}$ of trial (DOT)], cows enrolled on the once-daily milking (ODM) group were offered up to $3 \mathrm{~kg}$ (as-fed) of pellets at their single milking, whereas twice-daily milking (TDM) cows were offered up to $1.5 \mathrm{~kg}$ of pellets at each milking, for a total of up to $3 \mathrm{~kg} / \mathrm{d}$ (as-fed) daily. The AMS management software recorded the exact amount of pellets dispensed per milking. After $14 \mathrm{~d}$, all cows were milked twice daily and were offered up to 1.5 
Table 1. Ingredient composition (\% of diet DM) and nutrient profile of postpartum partial mixed ration (PMR) and TMR diets in a randomized controlled trial examining reducing milking frequency as an adjunct treatment for ketosis

\begin{tabular}{|c|c|c|}
\hline Item & $\begin{array}{c}\text { AMS } \\
\text { pen - } \mathrm{PMR}^{1}\end{array}$ & $\begin{array}{c}\text { Box stall } \\
\text { pens - TMR }\end{array}$ \\
\hline \multicolumn{3}{|l|}{ Ingredient ( $\%$ of diet DM) } \\
\hline Straw, long chop & 2.1 & 3.6 \\
\hline Haylage & 37.5 & 32.0 \\
\hline Corn silage & 37.8 & 31.4 \\
\hline High-moisture corn & 10.3 & 19.4 \\
\hline Dairy supplement $\operatorname{mix}^{3,4}$ & 2.3 & 2.3 \\
\hline SoyPlus & 6.3 & 5.8 \\
\hline Soybean meal & 2.5 & 3.6 \\
\hline Canola & 0.8 & 1.3 \\
\hline Fish meal (herring) & 0.4 & 0.6 \\
\hline \multicolumn{3}{|l|}{ Formulated composition } \\
\hline Forage $(\%$ of DM) & 77.4 & 67.1 \\
\hline ME (\% of required) & 104.5 & 104.7 \\
\hline $\mathrm{NFC}(\%$ of DM) & 38.9 & 41.7 \\
\hline Starch (\% of DM) & 22.0 & 25.8 \\
\hline Sugar (\% of DM) & 1.9 & 2.1 \\
\hline $\mathrm{ADF}(\%$ of $\mathrm{DM})$ & 22.1 & 20.3 \\
\hline $\mathrm{NDF}(\%$ of $\mathrm{DM})$ & 33.6 & 31.4 \\
\hline MP supply (g) & $2,157.7$ & $2,641.5$ \\
\hline $\mathrm{CP}(\%$ of $\mathrm{DM})$ & 16.3 & 16.1 \\
\hline $\mathrm{SP}(\%$ of $\mathrm{CP})$ & 48.2 & 46.7 \\
\hline $\mathrm{RDP}(\%$ of DM) & 10.3 & 9.8 \\
\hline $\mathrm{Ca}(\%$ of $\mathrm{DM})$ & 0.8 & 0.8 \\
\hline $\mathrm{P}(\%$ of $\mathrm{DM})$ & 0.4 & 0.4 \\
\hline $\mathrm{Mg}(\%$ of $\mathrm{DM})$ & 0.4 & 0.4 \\
\hline $\mathrm{K}(\%$ of $\mathrm{DM})$ & 1.3 & 1.3 \\
\hline $\mathrm{NE}_{\mathrm{L}}(\mathrm{Mcal} / \mathrm{kg}$ of $\mathrm{DM})$ & 1.6 & 1.7 \\
\hline
\end{tabular}

${ }^{1}$ Automated milking system pen: pen where cows were housed when deemed sufficiently health to leave the individual box stalls; PMR.

${ }^{2}$ Box stall pens: pen where cows freshened and remained until deemed sufficiently healthy to be moved to the AMS pen; TMR.

${ }^{3}$ Composition of dairy supplement ( $\%$ of mix DM) in the AMS pen: $51.06 \%$ bypass protein (SoyPlus, Dairy Nutrition Plus); $20.06 \%$ soybean meal; $6.85 \%$ canola; $4.67 \%$ sodium sesquicarbonate; $4.13 \%$ fine salt; $3.61 \%$ fish meal (herring); $3.02 \%$ monocalcium phosphate; $2.03 \%$ yeast culture (Diamond V, XP); $1.24 \%$ magnesium oxide; $1.1 \%$ tallow; $0.9 \%$ vitamin-mineral micro-premix; $0.53 \%$ calcium carbonate; $0.37 \%$ methionine (MetaSmart, Adisseo); $0.35 \%$ granular sulfur; $0.05 \%$ monensin (Rumensin Premix, Elanco), 0.03\% selenium yeast (Sel-Plex, Alltech).

${ }^{4}$ Composition of dairy supplement (\% of mix DM) in the box stall pens: $42.3 \%$ bypass protein (SoyPlus, Dairy Nutrition Plus); $26.8 \%$ soybean meal; $9.81 \%$ canola; $3.7 \%$ sodium sesquicarbonate; $4.13 \%$ fine salt; $4.13 \%$ fish meal (herring); $2.2 \%$ monocalcium phosphate; $1.6 \%$ yeast culture (Diamond V, XP); $1.31 \%$ magnesium oxide; $0.55 \%$ tallow; $0.83 \%$ vitamin-mineral micro-premix; $2.03 \%$ calcium carbonate; $0.27 \%$ methionine (MetaSmart, Adisseo); $0.3 \%$ granular sulfur; $0.04 \%$ monensin (Rumensin Premix, Elanco), 0.02\% selenium yeast (SelPlex, Alltech); $0.76 \%$ potassium carbonate.

$\mathrm{kg}$ (as-fed) of pellets at each milking until the end of the trial. Diets and pellet composition are described in Tables 1 and 2, respectively.

\section{Inclusion Criteria and Sample Size Calculation}

To be eligible for enrollment, fresh cows could not have had a cesarean section at calving or experienced milk fever or a displaced abomasum within their first 3 DIM.

The main outcome of interest was the resolution of ketosis (blood BHB $<1.2 \mathrm{mmol} / \mathrm{L}$ ). Sample size calculation for 2 proportions was based on the probability of cure of ketosis, with an expectation of $75 \%$ in the ODM treatment versus the current standard of $50 \%$ within 4 to $5 \mathrm{~d}$ of treatment (McArt et al., 2011; Gordon et al., 2013). Detection of this treatment difference, with $80 \%$ power and $95 \%$ confidence, yielded a minimal sample size of 58 animals per group. A targeted sample of 60 animals per treatment group was set allowing for losses to follow-up.

\section{Study Design and Treatment Groups}

After calving, cows were screened for ketosis daily from 3 to 16 DIM using whole blood samples tested with a Precision Xtra point-of-care meter (Abbott Laboratories). Cows were enrolled in the trial upon ketosis detection (first blood BHB $\geq 1.2 \mathrm{mmol} / \mathrm{L}$; Oetzel, 2004; Duffield et al., 2009). At enrollment, a health event was entered into the herd management software (Dairy Comp 305 system; Valley Ag Software), so that cows appeared on the daily treatment list for the farm employees.

From calving until ketosis diagnosis all cows were milked twice daily. When diagnosed with ketosis, cows were randomly allocated to 1 of 2 treatment groups: the ODM or TDM milking group. Treatment allocation was blocked by parity (separate treatment allocation chart for primiparous and multiparous cows). A coin

Table 2. Nutrient profile (\% of DM unless otherwise noted) of the automated milking system (AMS) pellets offered to cows housed in the AMS pen in a randomized controlled trial examining reducing milking frequency as an adjunct treatment for ketosis

\begin{tabular}{lc}
\hline Formulated composition & AMS pellet \\
\hline $\mathrm{DM}$ (\% of total) & 88.9 \\
$\mathrm{NE}_{\mathrm{L}}$ (Mcal/kg of DM) & 1.5 \\
$\mathrm{CP}$ & 18.2 \\
Soluble protein $(\%$ of $\mathrm{CP})$ & 5.1 \\
Lysine & 0.9 \\
Methionine & 0.2 \\
Crude fat & 2.0 \\
Crude fiber & 9.7 \\
$\mathrm{ADF}$ & 12.7 \\
$\mathrm{NDF}$ & 24.4 \\
$\mathrm{Ca}$ & 0.6 \\
$\mathrm{P}$ & 0.5 \\
Ash & 5.5 \\
$\mathrm{Na}$ & 0.2 \\
$\mathrm{Cl}$ & 0.4 \\
$\mathrm{~K}$ & 1.0 \\
$\mathrm{Mg}$ & 0.4 \\
$\mathrm{~S}$ & 0.2 \\
\hline
\end{tabular}


toss was used to ensure random treatment allocation. In a 10-treatment block, once a treatment had been assigned 5 times, the remaining slots were assigned to the opposite treatment. The 10-treatment block was repeated until the trial was finished. Regardless of group assignment, all cows diagnosed with ketosis were treated with $300 \mathrm{~mL}$ of oral PG once per day for $5 \mathrm{~d}$ beginning in the afternoon on the day of their first BHB test $\geq 1.2 \mathrm{mmol} / \mathrm{L}$. Ketosis treatment was administered by trained staff. Considering the study design, it was not possible to blind farm staff and researchers to the treatment group. However, the outcomes assessed were objective.

Once a cow was enrolled in the treatment trial, they were tested for ketosis for the first $3 \mathrm{~d}$ following diagnosis, and then every third day, for a total of $21 \mathrm{~d}$ (Supplemental Table S1; http://dx.doi.org/10.17632/ 9ycrchbp6b.1, Couto Serrenho, 2021). The research team performed the blood sampling. Cows that were still in a box stall at the time of their ketosis diagnosis had a sign attached to their stall indicating their MF. Cows located in the box stalls enrolled in the ODM group were only milked in the morning, and cows in the TDM group were milked in the morning and in the evening.

In the freestall pen (AMS pen), AMS time-constraint and milking frequency protocol settings, as well as pellet allowance, were changed at the time of ketosis diagnosis and reset on the morning of the 15th DOT. Cows in the ODM group were not allowed in the AMS for $23 \mathrm{~h}$ following their last milking, creating a milking interval of $1 \mathrm{~d}$. Cows in the TDM group were not allowed in the AMS for $11 \mathrm{~h}$ following their last milking and were milked $2 \times$ throughout the trial without changing pellet allowance per milking.

In the AMS, an overdue milking alert was programmed for the 23-h interval mark. Similarly, the cows enrolled in the TDM group were given an 11-h milking interval, with the overdue milking alert at the 11-h interval mark. The milking status of cows was regularly checked by the farm staff and cows were fetched if overdue for the robot throughout the day between 0500 and $1900 \mathrm{~h}$. The AMS software created a milking priority queue, labeling cows on a color basis (yellow: eligible to be milked; red: milking overdue). The labeling system allowed staff to easily set cows' milking priority. This ensured that cows were milked as closely as possible to the 24 -h or the 12 -h mark. In both groups, cows that had been incompletely milked (defined by the DeLaval VMS AMS software) were required to wait until their next designated milking time.

Propylene glycol drenching (5 consecutive days of $300 \mathrm{~g}$ of oral PG) was repeated in cows in both ODM and TDM that had blood BHB $\geq 1.2 \mathrm{mmol} / \mathrm{L}$ after the first course of treatment with PG, as follows. A second treatment (additional 5 consecutive d of $300 \mathrm{mg}$ of oral PG) could only start at the ninth DOT (4 d after finishing the first course of PG treatment) or later. This allowed time to assess the effect of treatment on health. If a third treatment was needed, it was started at least $1 \mathrm{~d}$ after the second course of treatment was finished. Cows could be given a maximum of 4 courses of $\mathrm{PG}$ treatments within the $21-\mathrm{d}$ period, with the final retreatment beginning on $\mathrm{d} 21$ if needed.

Down cows, cows that developed a displaced abomasum, and cows that were seriously injured or ill were removed from the trial. Serious injury and illness was diagnosed by the veterinarian, who required removal of those cows from the trial.

Cows remained in the AMS pen until at least $21 \mathrm{~d}$ after enrollment. Milk production was monitored for the first 15 wk following enrollment in all cows. From wk 3 to 15 of the trial, all cows were milked twice daily. In this period, they could have been milked in the box stalls, by the AMS, or in the rotary parlor depending on the farm management, but their diets and other management were similar.

The voluntary waiting period for all cows was set at 50 DIM. Between 50 and 75 DIM cows were inseminated upon heat detection (activity monitoring, visual observation, or both). When not inseminated by 75 DIM, a timed-AI protocol (Ovsynch56; Dairy Cattle Reproduction Council, 2018) was applied.

\section{Data Collection (Blood BHB, Milk Production, and Feed Intake)}

All blood samples were collected between 0700 and $1000 \mathrm{~h}$, before the morning feeding. Blood (0.1 to 0.5 $\mathrm{mL}$ ) was collected from the coccygeal vein using a 20 -gauge needle attached to a $1-\mathrm{mL}$ syringe. Immediately after collection, blood was tested using a BHB strip and a Precision Xtra meter, previously validated in cattle (Iwersen et al., 2009; Voyvoda and Erdogan, 2010).

Daily milk yield data were collected from the milking equipment software system, DeLaval DelPro. There was a separate computer for each of the milking systems (box stalls, parlor, and AMS). Weekly milk samples collected by a DHIA customer service representative were measured in a DHIA laboratory (Lactanet) for fat and protein percentages, and SCC linear score (LS; base 2 log-transformation of SCC, Kirk, 1984). Energy-corrected milk was calculated by standardizing milk production to $3.5 \%$ fat and $3.2 \%$ protein using the following formula (Bernard, 1997): 


$$
\begin{gathered}
\mathrm{ECM}, \mathrm{kg}=(0.3246 \times \mathrm{kg} \text { of milk }) \\
+(12.86 \times \mathrm{kg} \text { of fat })+(7.04 \times \mathrm{kg} \text { of protein }) .
\end{gathered}
$$

Daily feed intake data were collected for each cow for $21 \mathrm{~d}$ after enrollment. In the AMS pen, Insentec feed bins (validated by Chapinal et al., 2007) recorded the time of the day, duration, and amount of PMR consumed each time a cow's transponder (located on a band around their neck) triggered the feed bin gate to open. Daily PMR intakes in the box stalls were measured once daily before PMR delivery. Feed samples from box stalls and AMS pen were collected once per week to measure ration DM (\%). The AMS measured the amount of pellets dispensed to each cow during milking, but we could not measure actual daily pellet consumption per cow. Thus, for the calculation of total DMI we assumed that all dispensed pellets were consumed. Due to AMS programming errors on the daily amount of pellets dispensed, discussed below, DMI is reported for the period of MF reduction (0 to 14 DOT).

DairyComp 305 was used to record information on health events within the first 60 DIM, estimated 305-d cumulative milk yield (305M) for cows that remained in the herd past 200 DIM, and reproductive events including DIM at first AI and pregnancy at first AI. Farm staff recorded disease events based on veterinary diagnosis and disease definitions described by Kelton et al. (1998).

\section{Statistical Analysis}

All data were stored in Microsoft Excel (Microsoft Corp.). Data for diseases, reproductive performance, and $305 \mathrm{M}$ were extracted from DC305 into Microsoft Excel. Daily milk yields until 15 wk following trial enrollment were collected from DeLaval DelPro and were compiled into weekly averages. Milk yield, milk fat and protein percentages, LS, and ECM were compiled as weekly data for each cow in the same database. Previous lactation $305 \mathrm{M}$ milk for multiparous cows and genomic estimated breeding values (GEBV; Holstein Canada, Brantford, ON) for milk in primiparous cows were used to compare pre-enrollment milk production characteristics of treatment groups. Individual feed intake data were collected and analyzed for the $21 \mathrm{~d}$ after enrollment.

Cows were excluded from all analyses if they were on their experimental treatment for $4 \mathrm{~d}$ or less. Cows were excluded from the feed intake analyses if they were missing intake data for at least the first $5 \mathrm{~d}$ after enrollment.

All statistical analyses were performed in SAS (version 9.4, SAS Institute Inc.). Descriptive statistics were generated with the MEANS and FREQ procedures in SAS. Fisher's exact test was used to evaluate the proportion of cows that needed additional PG treatments. In all models, cow was the experimental unit.

A binary logistic regression model (GLIMMIX procedure in SAS) accounting for repeated measures (_RESIDUAL_ in the RANDOM statement; Kiernan, 2018) was used to evaluate the resolution of ketosis (primary outcome). Cows were either classified as ketotic or nonketotic based on whether blood BHB $\geq 1.2 \mathrm{mmol} / \mathrm{L}$ at each sampling point. Day of trial $=0$ (first DOT) was not considered for this analysis because all cows had a blood $\mathrm{BHB} \geq 1.2 \mathrm{mmol} / \mathrm{L}$ at this time.

Linear regression models (MIXED procedure in SAS) accounting for repeated measures were used to evaluate the effect of treatment on all continuous outcomes (BHB concentration, milk yield, ECM, milk fat and protein percentages, LS, and total DMI (in the AMS pen: sum of PMR and robot pellet DMI; in the box stalls: TMR DMI). The residuals of linear models were assessed with kurtosis, skewness, extreme observations, residual plots, and tests for normality (Shapiro-Wilk, Kolmogorov-Smirnov, Cramer-von Mises, and Anderson-Darling). Based on the residual analyses, outcome variables were transformed and outliers were assessed. Outliers were removed if they appeared to be a reporting error.

Time to first AI and pregnancy to first AI (binary outcomes) were analyzed using logistic regression models (GLIMMIX procedure of SAS) with treatment group, parity group (first or $\geq$ second), and their interactions. Time to first AI was analyzed with Cox's proportional hazards regression (the PHREG procedure in SAS).

For the resolution of ketosis and $\mathrm{BHB}$ concentration models, in addition to the treatment group (main effect), DOT (linear and quadratic), parity (first or $\geq$ second), as well as all 2-way and 3-way interactions with treatment were offered to the models. The final model for resolution of ketosis required DOT to be included as a quadratic variable $\left(\mathrm{DOT}^{2}\right)$. A ln transformation was required for the BHB concentration final model, and DOT needed to be included as a quadratic effect.

For the milk yield, milk components, and LS models, in addition to the treatment group, parity (first, second, and $\geq$ third) and sampling time (in wk, linear and quadratic) were offered to the models. In the $305 \mathrm{M}$ model, in addition to the treatment group, parity group (second and $\geq$ third lactation) and previous lactation $305 \mathrm{M}$ were offered to the model. The $305 \mathrm{M}$ model for primiparous cows was built separately without previous lactation $305 \mathrm{M}$ data.

All final models included the variables treatment and parity nested within cow as repeated measures. Covariance structure selection was based on the low- 
est Akaike's information criterion for the final model. Heterogeneous Toeplitz covariance structure was used for the resolution of ketosis, BHB concentration, milk fat percentage, LS, and DMI models, whereas an unstructured covariance structure was used for milk yield, ECM, and milk protein percentage models. Covariates and their interaction terms were manually removed by backward stepwise elimination if $P>0.05$. When an effect of treatment was detected, multiple comparisons were assessed with Tukey-Kramer approach (ADJUST $=$ TUKEY in the LSMEANS statement). When transformations were applied, least squares means (LSM) results were back-transformed and presented with their $95 \%$ confidence interval.

\section{Deviation from the Protocol}

Due to AMS programming errors, not all enrolled cows followed the predefined protocol regarding daily pellet allowance. During sample collection, it was noticed that 8 of 48 cows from the ODM were not allowed to receive $3 \mathrm{~kg}$ (as-fed) of pellets during milking. Instead, due to a programming error when these cows were moved from the box stalls to the AMS pen, they received $1.5 \mathrm{~kg}$ of pellets for a few days on trial. This was noticed early on and corrected immediately. The total DMI and milk production data were analyzed with and without these cows. Their removal did not affect the interpretation of the results and they were kept in the analyses.

When analyzing the DMI data, we realized that when returned to a twice daily milking schedule (14th DOT), all ODM cows were given $3 \mathrm{~kg}$ of pellets per milking $(6 \mathrm{~kg} / \mathrm{d})$ instead of $3 \mathrm{~kg} / \mathrm{d}$ as planned. This contrasts with the amount of pellets programmed to be offered to TDM cows in the same period of the trial period (1.5 $\mathrm{kg} /$ milking or $3 \mathrm{~kg} / \mathrm{d}$ ). Thus, total DMI is reported until the 14th DOT.

\section{RESULTS}

During the screening period, $70.3 \%(\mathrm{n}=104)$ of 148 cows tested positive for ketosis and 90.3\% $(\mathrm{n}=94)$ of 104 cows completed the 21-d trial period. A data flowchart of the trial enrollment and completion is presented in Figure 1. Twenty-one primiparous and 34 multiparous cows were enrolled in the ODM group and 18 primiparous and 31 multiparous cows were enrolled in the TDM group. A total of 10 enrolled cows (5 ODM and 5 TDM) did not complete the trial; 4/5 ODM and $2 / 5$ TDM cows left the trial within the first $4 \mathrm{~d}$ on trial (thus, were not included in the analyses). The descriptive statistics of DIM and blood BHB concentration at enrollment, as well as health events within the first 60 DIM, by treatment group are described in Table 3 .

\section{Resolution of Ketosis (Blood BHB $<1.2 \mathrm{mmol} / \mathrm{L}$ ) and Additional PG Treatments}

There was a 3-way interaction of treatment group, day of trial, and parity group $(P<0.01)$, so results were stratified by parity (Figure $2 \mathrm{a}$ and $2 \mathrm{~b}$ ). In primiparous (Figure $2 \mathrm{a}, P<0.01$ ) and multiparous cows (Figure $2 \mathrm{~b} ; P \leq 0.05$ ), the ODM group was less likely to have ketosis from 2 to 21 DOT than the TDM group. In both parity groups, the difference between the 2 treatment groups persisted beyond the $14 \mathrm{~d}$ of MF reduction (Figure 2).

A greater proportion of the cows in the TDM group received additional $\mathrm{PG}$ treatments than the cows in the ODM group $(P<0.04)$; the number of additional PG treatments per treatment group is described in Table 4 .

\section{Blood BHB Concentration}

There was a 3-way interaction of treatment group, DOT, and parity group $(P<0.01)$. Cows in ODM group had lower blood BHB concentration (primiparous cows: from 1 to 12 DOT; multiparous cows: 1 to 21 DOT) than cows in the TDM group (Table 5 ). In primiparous cows, after the end of treatment period (14 DOT), BHB concentration between groups was no longer significant $(P>0.08)$. Multiparous ODM cows maintained lower BHB concentrations than multiparous TDM cows for the full week following MF reduction ending (15 to 21 DOT; $P<0.001)$.

\section{Milk Production and Components}

Previous lactation 305 milk yield for multiparous cows $(P=0.75)$ and GEBV for milk in the primiparous cows $(P=0.15)$ were not different between treatment groups. Of the 104 enrolled cows in the trial, milk production data from 6 cows were not included in the milk production and components analyses because they left the trial within $4 \mathrm{~d}$ of enrollment. The final milk production analyses include 98 cows (51 ODM; 47 TDM); 93 of 98 cows completed the 15-wk of monitoring period. From calving until the day before ketosis event $(-1 \mathrm{~d})$, first-lactation cows $(\mathrm{n}=37)$ produced on average $20.5 \mathrm{~kg} / \mathrm{d} \pm 4.3$ (SD) of milk (ODM: $21.3 \pm 5.1$ $\mathrm{kg} / \mathrm{d}$; TDM: $19.6 \pm 3.2 \mathrm{~kg} / \mathrm{d}$ ); second-lactation cows $(\mathrm{n}=31)$ produced $29.3 \pm 6.0(\mathrm{ODM}: 27.7 \pm 6.5 \mathrm{~kg} / \mathrm{d}$; TDM: $31.2 \pm 4.9 \mathrm{~kg} / \mathrm{d}$ ); and third or greater lactation cows $(\mathrm{n}=30)$ produced $26.1 \pm 9.1$ (ODM: $24.1 \pm 8.4$ $\mathrm{kg} / \mathrm{d}$; TDM: $28.0 \pm 9.5 \mathrm{~kg} / \mathrm{d}$ ). 


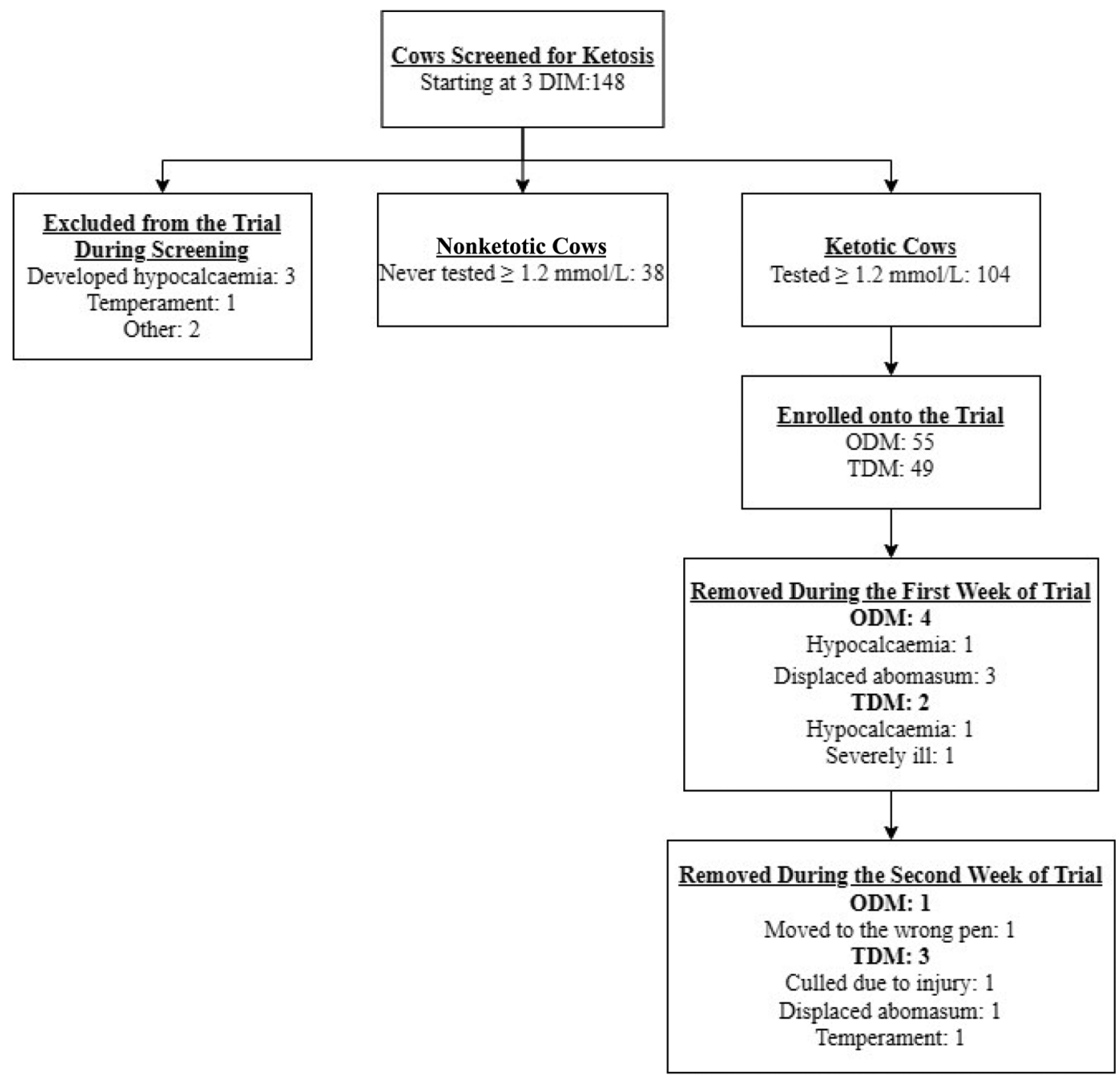

Figure 1. Flowchart of cows enrolled in the study including excluded animals and respective reasons during trial for Holstein cows in a randomized controlled trial where cows were milked twice daily (TDM, control), or once daily (ODM) for 2 wk, and twice daily thereafter following the detection of ketosis (blood BHB $\geq 1.2 \mathrm{mmol} / \mathrm{L}$ ). The removal of the 3 cows during the first week of the trial for displaced abomasum occurred within the same calendar week.

Table 3. Descriptive statistics of once-daily (ODM) and twice-daily (TDM) milked Holstein cows in a randomized controlled trial where cows were milked ODM or TDM for $14 \mathrm{~d}$ following the detection of ketosis

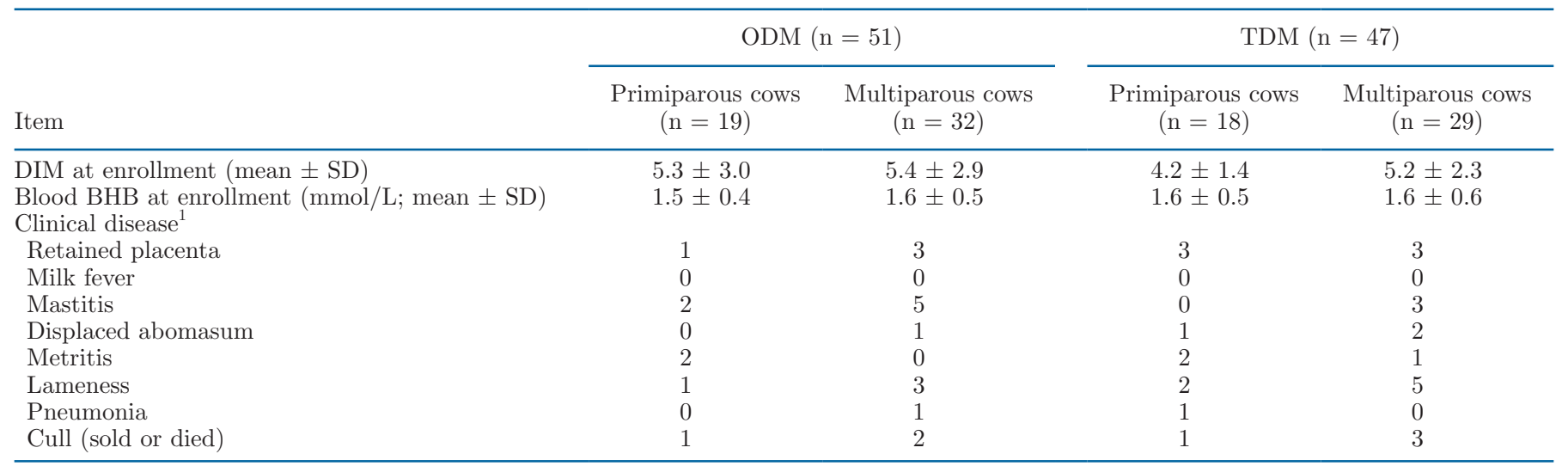

${ }^{1}$ Number of disease events occurring between 3 and 60 DIM. 

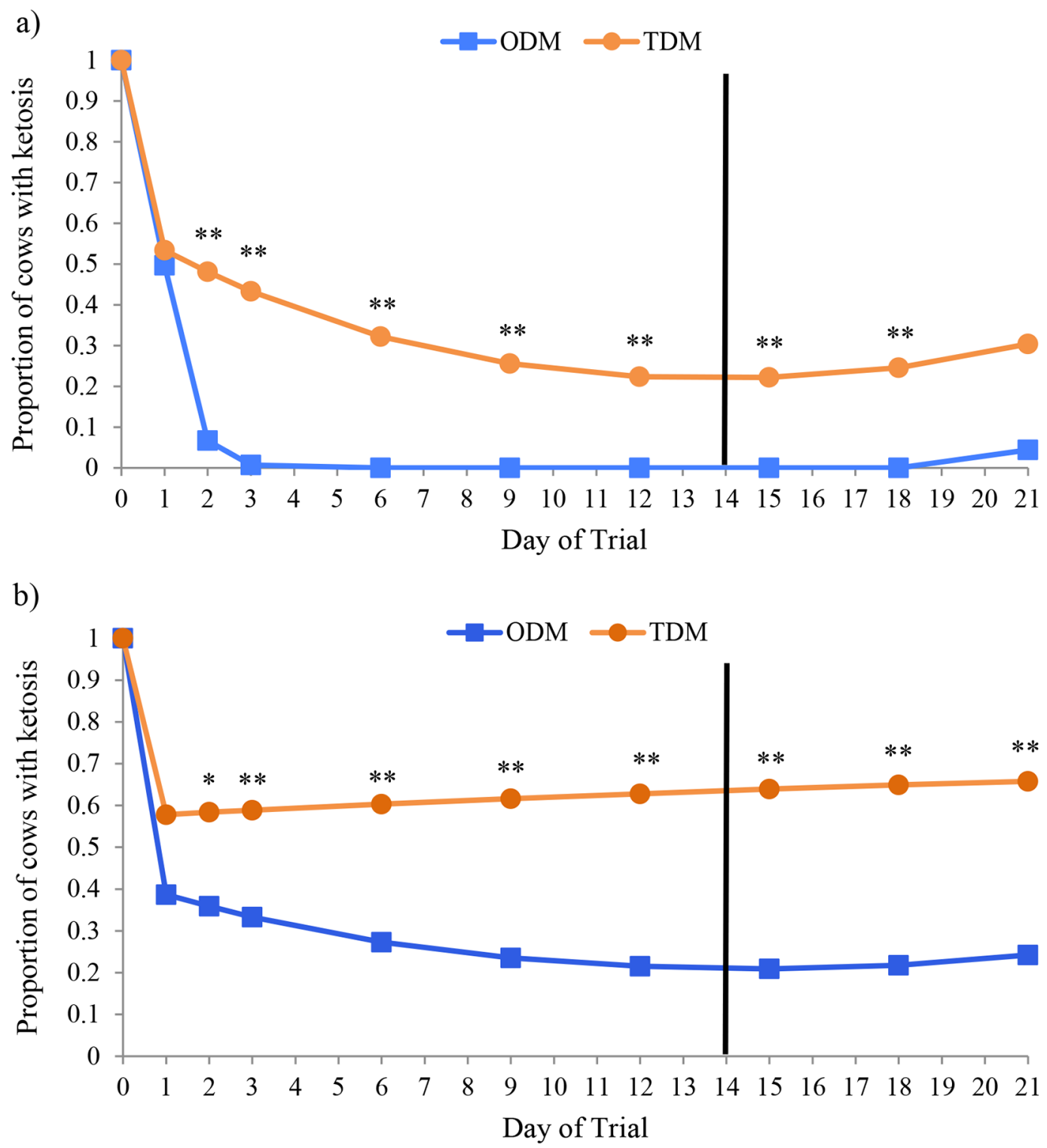

Figure 2. Proportions (LSM) of (a) primiparous $[\mathrm{n}=19$ once-daily milked (ODM); 18 twice-daily milked (TDM)] and (b) multiparous (n $=32 \mathrm{ODM} ; 29$ TDM) Holstein cows in a randomized controlled trial milked OD6M or TDM for $14 \mathrm{~d}$ (and twice daily thereafter) following the detection of ketosis (blood $\mathrm{BHB} \geq 1.2 \mathrm{mmol} / \mathrm{L}$ ). There were 3 -way interactions for treatment by parity by day of trial $(P=0.003)$ and treatment by parity by day of $\operatorname{trial}^{2}(P=0.003)$. Within a day, $* *$ denotes effect of the milking frequency treatment with $P \leq 0.01, *$ denotes $P<0.05$. The line at day of trial 14 marks the end of the treatment period. Comparisons were assessed using a Tukey-Kramer adjustment.

In both milk yield and ECM models, there was an interaction of treatment by week $^{2}$ of trial (following enrollment; $P=0.001$ and $P=0.0015$, respectively) and an interaction of treatment by lactation group $(P$ $=0.01)$. Milk yield of first- and second-lactation cows was lower in the ODM group than in the TDM group up to 4 and 8 wk of trial, respectively $(P<0.05)$. In first-lactation cows, ECM of ODM cows during the first 3 wk of trial was less than TDM cows (Figure 3b); in second-lactation cows, ECM was not different between groups $(P>0.06$, Figure $3 \mathrm{~b})$. Third- or greater- lactation cows in the ODM group produced less milk (average difference: $7.5 \mathrm{~kg} / \mathrm{d}$ milk yield and $13.6 \mathrm{~kg} / \mathrm{d}$ ECM) than cows in the TDM treatment group during the 15-wk study (Figure 3a,b).

In first-lactation cows, peak milk yield was observed at 10 wk after enrollment (ODM: $32.0 \mathrm{~kg} / \mathrm{d} \pm 1.0 \mathrm{SEM}$; TDM: $34.8 \mathrm{~kg} / \mathrm{d} \pm 1.1 \mathrm{SEM})$. In second-lactation cows, peak milk yield was observed at $10 \mathrm{wk}$ in the ODM group $(40.7 \mathrm{~kg} / \mathrm{d} \pm 1.1 \mathrm{SEM})$ and $7 \mathrm{wk}$ in the TDM group $(45.1 \mathrm{~kg} / \mathrm{d} \pm 1.2 \mathrm{SEM})$. Third-lactation cows peaked at $9 \mathrm{wk}$ for ODM $(39.1 \mathrm{~kg} / \mathrm{d} \pm 1.2 \mathrm{SEM})$ and 
Table 4. Summary of propylene glycol (PG) treatments administered during the $21 \mathrm{~d}$ after enrollment in a randomized controlled trial where ketotic cows were milked once (ODM) or twice (TDM) daily for $14 \mathrm{~d}$ following the detection of ketosis

\begin{tabular}{|c|c|c|c|c|c|c|c|}
\hline \multirow{3}{*}{$\begin{array}{l}\mathrm{PG} \\
\text { treatment }^{1}\end{array}$} & \multicolumn{6}{|c|}{ Treatment group } & \multirow[b]{3}{*}{$P$-value ${ }^{2}$} \\
\hline & \multicolumn{3}{|c|}{ ODM } & \multicolumn{3}{|c|}{ TDM } & \\
\hline & $\mathrm{n}$ treated & $\mathrm{n}$ total & $\%$ & $\mathrm{n}$ treated & $\mathrm{n}$ total & $\%$ & \\
\hline First & 51 & 51 & 100 & 47 & 47 & 100 & - \\
\hline Second & 20 & 51 & 39 & 30 & 47 & 64 & 0.02 \\
\hline Third & 7 & 50 & 14 & 22 & 44 & 50 & 0.01 \\
\hline Fourth & 0 & 50 & 0 & 16 & 43 & 37 & 0.04 \\
\hline
\end{tabular}

${ }^{1} \mathrm{PG}$ treatment: 5 -d treatment of oral propylene glycol (300 g) beginning on the afternoon of the ketosis diagnosis (blood BHB $\geq 1.2 \mathrm{mmol} / \mathrm{L}$ ); cows received additional 5-d PG treatments if they did not recover or relapsed after the initial treatment, starting on d 9 of the trial (blood BHB was measured for the first $3 \mathrm{~d}$ after ketosis diagnosis, and then once every $3 \mathrm{~d}$ for $21 \mathrm{~d}$ ).

${ }^{2}$ Fisher's exact test.

TDM $(45.4 \mathrm{~kg} / \mathrm{d} \pm 1.2 \mathrm{SEM})$ groups (Figure 3a). In first and second-lactation cows, the largest difference in milk yield between groups occurred at wk 1 with the ODM producing 7.9 and $13.5 \mathrm{~kg} / \mathrm{d}$ less milk, respectively, than the TDM cows $(P<0.0001)$. In third- or greater-lactation cows, the largest difference was observed at wk 15, with ODM cows producing $9.7 \mathrm{~kg} / \mathrm{d}$ less than TDM cows $(P<0.0001)$; at wk 1 , the difference between groups was $9.1 \mathrm{~kg} / \mathrm{d}$ between groups $(P$ $=0.0004)$.
In first-lactation cows, peak ECM yield was observed at 10 wk after enrollment (ODM: $33.9 \mathrm{~kg} / \mathrm{d} \pm 1.2 \mathrm{SEM}$; TDM: $35.8 \mathrm{~kg} / \mathrm{d} \pm 1.2 \mathrm{SEM})$. In second-lactation cows, peak ECM yield was observed at 7 wk in the ODM group $(47.5 \mathrm{~kg} / \mathrm{d} \pm 1.4 \mathrm{SEM})$ and at $2 \mathrm{wk}$ in the TDM group $(49.6 \mathrm{~kg} / \mathrm{d} \pm 1.7 \mathrm{SEM})$. Third-lactation cows ECM peak yield occurred at 9 wk for ODM $(39.1 \mathrm{~kg} / \mathrm{d}$ $\pm 1.2 \mathrm{SEM})$ and at wk 1 for TDM $(54.3 \mathrm{~kg} / \mathrm{d} \pm 1.8$ $\mathrm{SEM}$ ) groups (Figure $3 \mathrm{~b}$ ). The largest difference in ECM yield between groups occurred at wk 1 with the

Table 5. Back-transformed LSM $(95 \%$ CI) of the ln blood BHB concentrations $(\mathrm{mmol} / \mathrm{L})$ of Holstein cows enrolled in a randomized controlled trial with once (ODM) or twice daily milking (TDM) for $14 \mathrm{~d}$ following the detection of ketosis (blood BHB $\geq 1.2 \mathrm{mmol} / \mathrm{L}$ at $\mathrm{d} 0)^{1}$

\begin{tabular}{|c|c|c|c|c|}
\hline \multirow[b]{2}{*}{ Parity group } & \multirow[b]{2}{*}{ DOT } & \multicolumn{2}{|c|}{ Treatment group } & \multirow[b]{2}{*}{$P$-value ${ }^{2}$} \\
\hline & & ODM & TDM & \\
\hline \multirow[t]{10}{*}{ Primiparous cows } & & $(\mathrm{n}=19)$ & $(\mathrm{n}=18)$ & \\
\hline & 1 & $0.92(0.80-1.06)$ & $1.22(1.02-1.47)$ & 0.05 \\
\hline & 2 & $0.84(0.74-0.96)$ & $1.16(0.96-1.39)$ & 0.02 \\
\hline & 3 & $0.78(0.69-0.88)$ & $1.10(0.90-1.33)$ & 0.01 \\
\hline & 6 & $0.64(0.57-0.72)$ & $0.96(0.75-1.23)$ & 0.02 \\
\hline & 9 & $0.57(0.51-0.64)$ & $0.87(0.65-1.17)$ & 0.03 \\
\hline & 12 & $0.54(0.48-0.61)$ & $0.82(0.60-1.13)$ & 0.05 \\
\hline & 15 & $0.55(0.49-0.61)$ & $0.81(0.59-1.11)$ & 0.08 \\
\hline & 18 & $0.59(0.53-0.67)$ & $0.83(0.61-1.13)$ & 0.12 \\
\hline & 21 & $0.69(0.60-0.80)$ & $0.89(0.63-1.24)$ & 0.50 \\
\hline \multirow[t]{10}{*}{ Multiparous cows } & & $(\mathrm{n}=32)$ & $(\mathrm{n}=29)$ & \\
\hline & 1 & $1.01(0.89-1.15)$ & $1.40(1.17-1.69)$ & 0.02 \\
\hline & 2 & $0.97(0.86-1.11)$ & $1.43(1.19-1.72)$ & $<0.01$ \\
\hline & 3 & $0.94(0.83-1.07)$ & $1.45(1.20-1.76)$ & $<0.01$ \\
\hline & 6 & $0.87(0.75-1.01)$ & $1.52(1.22-1.90)$ & $<0.001$ \\
\hline & 9 & $0.82(0.69-0.96)$ & $1.58(1.23-2.03)$ & $<0.001$ \\
\hline & 12 & $0.79(0.67-0.94)$ & $1.62(1.24-2.12)$ & $<0.0001$ \\
\hline & 15 & $0.78(0.66-0.93)$ & $1.65(1.26-2.17)$ & $<0.0001$ \\
\hline & 18 & $0.80(0.68-0.94)$ & $1.67(1.27-2.19)$ & $<0.0001$ \\
\hline & 21 & $0.83(0.69-1.00)$ & $1.67(1.24-2.25)$ & $<0.001$ \\
\hline
\end{tabular}

${ }^{1}$ After $14 \mathrm{~d}$ of trial (DOT), all cows were milked twice daily and their blood BHB concentrations were assessed until 21 DOT. There was a 3 -way interaction of treatment group $\times(\mathrm{DOT})^{2} \times$ parity group $(P<0.01)$.

${ }^{2}$ Adjusted for multiple comparisons (Tukey-Kramer). 
Table 6. Milk components and linear score (LSM \pm SEM) for Holstein cows in a randomized controlled trial where cows were milked twice daily (TDM, control), or once daily (ODM) for $14 \mathrm{~d}$, and twice daily thereafter over a period of $15 \mathrm{wk}$ following the detection of ketosis and trial enrollment

\begin{tabular}{lccrrrr}
\hline & \multicolumn{2}{c}{ Treatment group } & & \multicolumn{3}{c}{$P$-value $^{1}$} \\
\cline { 2 - 3 } \cline { 5 - 7 } Item & ODM $(\mathrm{n}=51)$ & TDM $(\mathrm{n}=47)$ & & TRT & WOT & Parity \\
\hline Fat (\%) & $4.30 \pm 0.05$ & $4.18 \pm 0.05$ & & 0.09 & $<0.0001$ & - \\
Protein $(\%)$ & $3.15 \pm 0.03$ & $3.04 \pm 0.03$ & & $<0.01$ & $<0.0001$ & - \\
Linear score $^{2}$ & $3.21 \pm 0.19$ & $2.70 \pm 0.19$ & & 0.06 & $<0.001$ & $<0.0001$ \\
\hline
\end{tabular}

${ }^{1}$ TRT $=$ effect of milking frequency treatment (ODM vs. TDM); WOT: week of trial (from zero until $15 \mathrm{wk}$ after enrollment); parity (first, second, or third and greater lactations). Variables were removed (-) from the model when $P>0.05$. All models accounted for repeated measures over $15 \mathrm{wk}$.

${ }^{2}$ Somatic cell count linear score.

ODM producing $7.8,6.2$, and $25.0 \mathrm{~kg} / \mathrm{d}$ less milk in first, second, and third or greater lactations, respectively, than the TDM cows $(P<0.001)$.

We did not detect interactions of treatment by parity group or week of sampling in milk fat percentage, milk protein percentage, or LS. Parity had no detected effect on milk fat $(P=0.85)$ or protein percentage $(P=$ $0.53)$. During the 15-wk study, in ODM cows, milk fat and protein were $0.12(P=0.09)$ and 0.11 percentage points greater $(P<0.01)$, respectively, than the milk fat and protein of TDM cows (Table 6). Cows in the ODM group tended to have a LS 0.51 points greater than cows on TDM group $(P=0.06)$ during the 15 -wk period following trial enrollment.

The $305 \mathrm{M}$ data only included cows that remained in the herd past 200 DIM (45 in ODM and 43 in TDM groups; 34 primiparous and 54 multiparous cows). Considering all cows, the ODM group tended to produce $537 \mathrm{~kg}(5 \%)$ less $305 \mathrm{M}$ than TDM cows $(10,254$ $\pm 203.8 \mathrm{~kg}$ and $10,791 \pm 206.1 \mathrm{~kg}$, respectively; $P=$ $0.07)$. When the previous $305 \mathrm{M}$ was included in the model (only multiparous cows) no difference was detected (ODM: 10,910 $\pm 245.6 \mathrm{~kg}$; TDM: 11,220 \pm 250.1 $\mathrm{kg}$, respectively; $P=0.31$ ) between treatment groups. a)

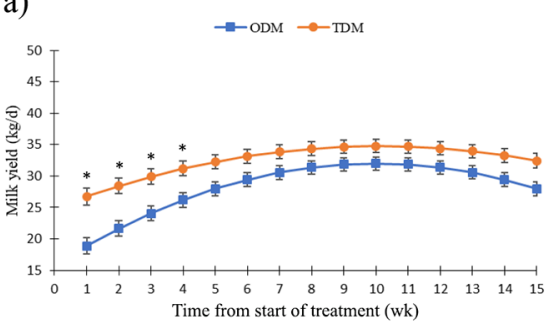

b)

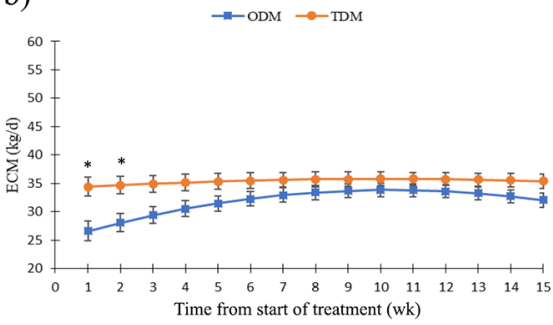

Second lactation cows

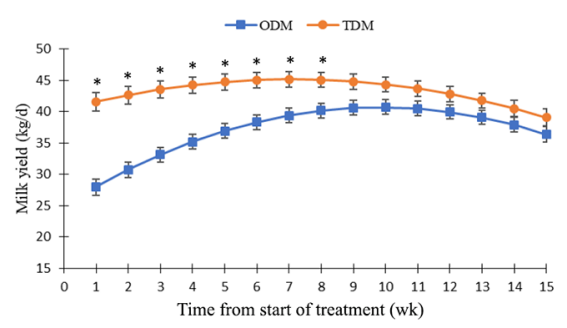

$\rightarrow-\mathrm{ODM} \rightarrow-\mathrm{TDM}$

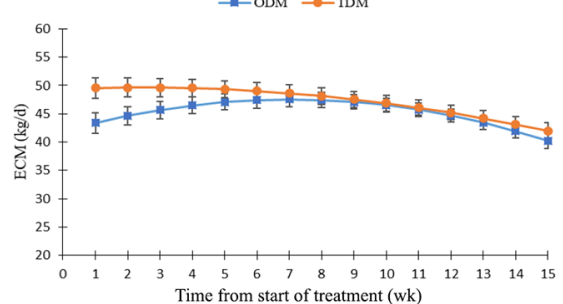

Third or greater lactation cows
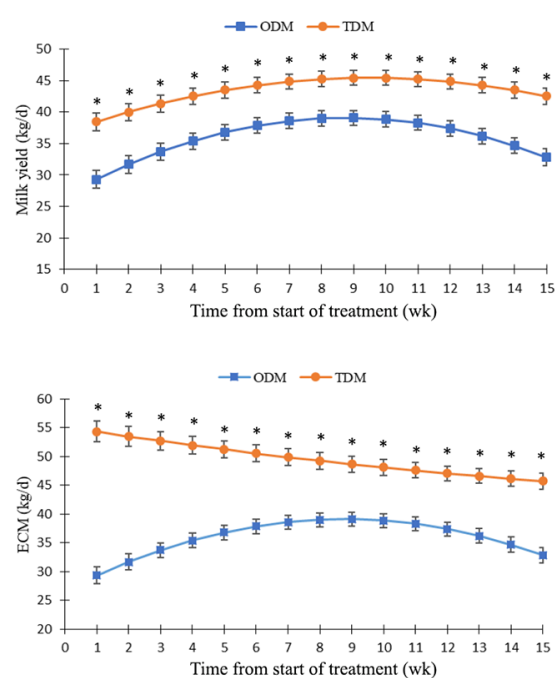

Figure 3. Milk yield (a) and ECM (b) (LSM \pm SEM; kg/cow per day) over a period of 15 wk for Holstein cows enrolled in a randomized controlled trial for first $[\mathrm{n}=19$ once-daily milked (ODM); 18 twice-daily milked (TDM)], second ( $\mathrm{n}=17$ ODM, 14 TDM), and third or greater lactations ( $\mathrm{n}=15$ ODM, 15 TDM). After enrollment, cows were milked once daily (ODM; $\mathrm{n}=51$ ), or twice daily (TDM; $\mathrm{n}=47$ ) for 2 wk, and twice daily thereafter, following the detection of ketosis (blood BHB $\geq 1.2 \mathrm{mmol} / \mathrm{L}$ ). There was an interaction treatment $\times$ week $^{2}$ and treatment $\times$ lactation group in both milk yield and ECM models $(P<0.01)$. In first and second-lactation cows, ${ }^{*}$ denotes a $P<0.05$; in thirdand greater-lactation cows ${ }^{*}$ denotes a $P \leq 0.001$. Comparisons were assessed using a Tukey-Kramer adjustment. Before ketosis event $(-1 \mathrm{~d})$, first-lactation ODM and TDM cows produced $21.3 \pm 5.1 \mathrm{SD}$ and $19.6 \pm 3.2 \mathrm{~kg} / \mathrm{d}$ of milk, respectively; second-lactation ODM and TDM cows produced $27.7 \pm 6.5$ and $31.2 \pm 4.9 \mathrm{~kg} / \mathrm{d}$, respectively; and third- or greater-lactation ODM and TDM cows produced $24.1 \pm 8.4 \mathrm{SD}$ and 28.0 $\pm 9.5 \mathrm{~kg} / \mathrm{d}$, respectively. 


\section{Reproductive Outcomes}

In the ODM and TDM groups, $55 \%$ and $65 \%$ of the cows, respectively, were inseminated following the timed-AI protocol. The proportion of cows inseminated [ODM: $92.2 \%$ (95\% CI: 80.7-97.1); TDM 91.5\% (95\% CI: $79.2-96.8) ; P=0.9]$ and time to first AI was not different between treatment groups [median time to first AI: ODM 84 (95\% CI: 73-87); TDM 87 (75-89) DIM; hazard ratio: 0.7 (95\% CI: $0.47-1.10) ; P=0.13]$. The proportion of cows pregnant at first AI was $45 \%(95 \%$ CI: $31.1-59.1)$ in ODM and 30\% (95\% CI: $18.3-45.6)$ in TDM (odds ratio $=1.86,95 \%$ CI: $0.77-4.50, P=0.16$ ).

\section{Dry Matter Intake}

Of the 104 cows enrolled on the trial, 92 cows were included in the feed intake analyses (6 were enrolled onto the trial for $4 \mathrm{~d}$ or less, and 6 were missing feed data for at least the first $5 \mathrm{~d}$ of trial).

The final total DMI model included parity group (primiparous vs. multiparous, $P<0.001)$, DOT $^{2}(P<$ $0.001)$, and the 2-way interaction of treatment group by DOT $(P<0.001$; Figure 4$)$. An interaction of treatment group by parity group was not detected. Cows in ODM increased their DMI at a greater rate (regression slope difference $0.15 \pm 0.05 \mathrm{~kg}$ of DM/DOT). On the first DOT, DMI was $13.4 \mathrm{~kg} / \mathrm{d}$ (95\% CI: 12.4 to 14.3 ) in ODM and $14.0 \mathrm{~kg} / \mathrm{d}$ (95\% CI: 13.0-14.9) in TDM $(P=0.40)$; on the seventh DOT, DMI in ODM was $16.2 \mathrm{~kg} / \mathrm{d}$ (95\% CI: $15.4-17.1)$ and $15.9 \mathrm{~kg} / \mathrm{d}(95 \% \mathrm{CI}$ : $15.0-16.8)$ in TDM $(P=0.57)$; on the 14 th DOT, DMI in ODM was $18.0 \mathrm{~kg} / \mathrm{d}$ (95\% CI: $17.1-19.0)$ and 16.6 $\mathrm{kg} / \mathrm{d}(95 \%$ CI: $15.6-17.6)$ in TDM $(P=0.04)$.

\section{DISCUSSION}

To our knowledge, this is the first randomized controlled trial to assess the effects of reduced MF as therapy for ketotic cows. The main objective was to assess the effects of implementing $1 \times$ milking on ketosis resolution and blood BHB concentration of ketotic dairy cows in early lactation. Most previous MF studies have either evaluated $1 \times$ milking as a metabolic stress reduction strategy, or as labor-saving opportunity in extensive farming systems where less emphasis is placed on milk production per cow (Clark et al., 2006; Stelwagen et al., 2013). We rejected the null hypothesis by observing an effect of reducing MF on resolution of ketosis. Our results support that reducing MF from $2 \times$ to $1 \times$, in conjunction with oral $\mathrm{PG}$, more effectively resolves ketosis and decreases blood BHB concentrations

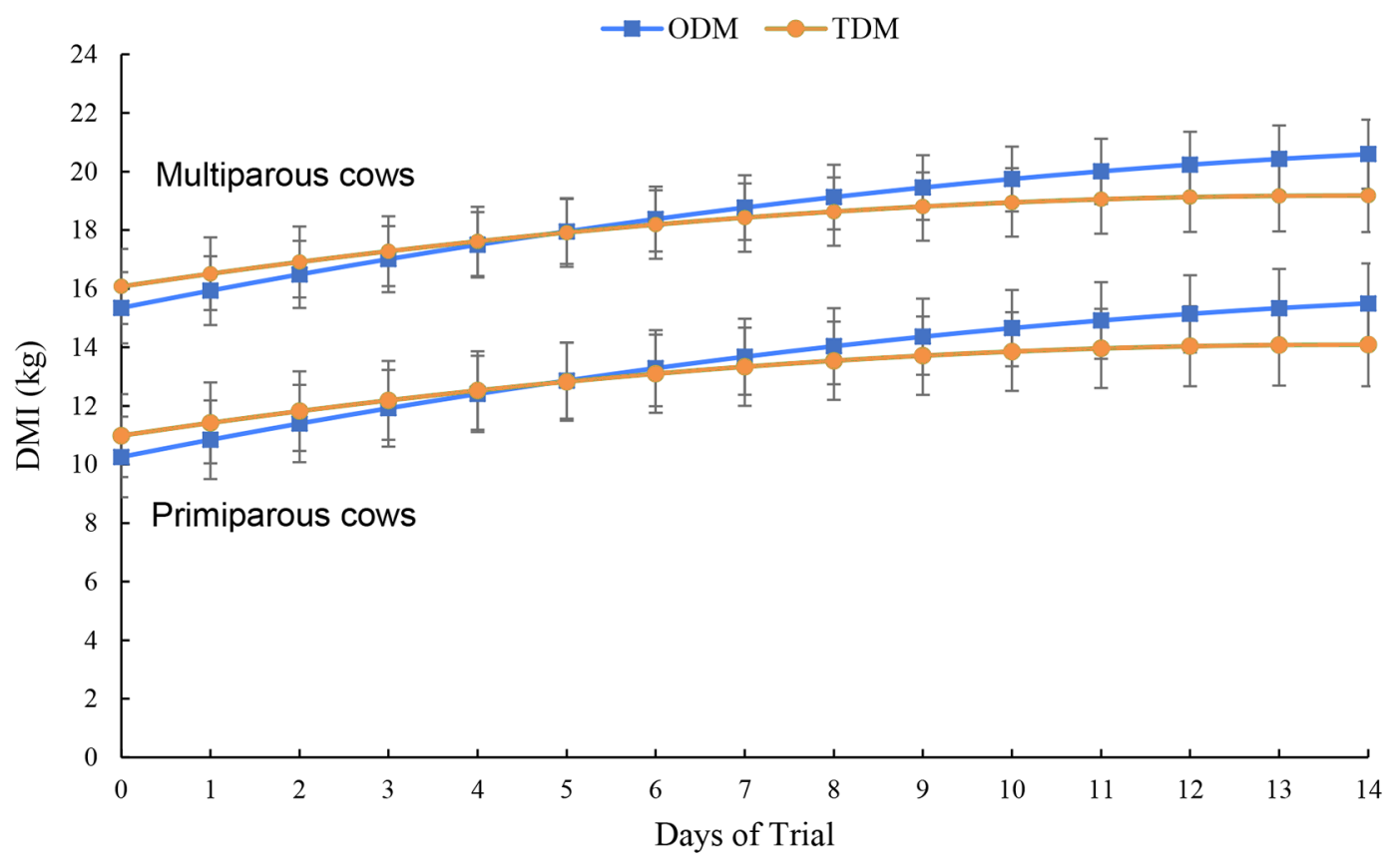

Figure 4. Dry matter intake $(\mathrm{kg} / \mathrm{d} ; \mathrm{LSM} \pm \mathrm{SEM})$ during the first $14 \mathrm{~d}$ of trial (DOT) for Holstein cows enrolled in a randomized controlled trial. After enrollment, cows were milked once daily (ODM; $\mathrm{n}=48$ ) or twice daily (TDM; $\mathrm{n}=44$ ) for 2 wk, and twice daily thereafter, following the detection of ketosis (blood BHB $\geq 1.2 \mathrm{mmol} / \mathrm{L}$ ). The final total DMI model included parity group (primiparous cows, $\mathrm{n}=39 \mathrm{vs}$. multiparous cows, $\mathrm{n}=53, P<0.001)$, DOT $^{2}(P<0.001)$, and the 2 -way interaction of treatment group by DOT $(P<0.01)$. Comparisons were assessed using a Tukey-Kramer adjustment. 
than treating ketotic cows with PG alone. However, in all parity groups, the MF reduction compromised milk yield during the treatment period ( $2 \mathrm{wk})$, and in third or greater lactation cows, for at least $13 \mathrm{wk}$ after the treatment period ended.

\section{Ketosis Resolution}

Primiparous and multiparous ODM cows were less likely to have blood $\mathrm{BHB} \geq 1.2 \mathrm{mmol} / \mathrm{L}$ compared with the TDM cows by the sixth DOT. Most of the cows achieved a blood BHB $<1.2 \mathrm{mmol} / \mathrm{L}$ by the sixth DOT, indicating that a full 2 -wk reduction of MF is probably not necessary to gain the metabolic benefits of $1 \times$ milking/d; perhaps the same duration as PG treatment ( $5 \mathrm{~d}$ ) may be sufficient. The number of additional PG treatments administered to each group supports the efficacy of the $1 \times$ milking/d treatment in resolving ketosis (or reducing the chronic or relapsed cases of ketosis), and demonstrates the inadequacy of extended PG treatments alone in resolving ketosis.

Researchers have previously demonstrated that healthy cows milked $1 \times$ for a 1 to 4 -wk period in early lactation had lower blood BHB concentrations than their $2 \times$ milked counterparts (Loiselle et al., 2009; Schlamberger et al., 2010; Kay et al., 2013). In a randomized controlled trial, Loiselle et al. (2009) assigned 22 multiparous cows to be milked $1 \times$ or $2 \times$ during the first wk postpartum, and $2 \times$ thereafter. Blood BHB concentrations in cows milked $1 \times$ remained lower than $2 \times$ milked cows (Loiselle et al., 2009). These findings are similar to studies evaluating the metabolic effects of incompletely milking cows in the first $5 \mathrm{~d}$ of lactation (Carbonneau et al., 2012; Morin et al., 2018). Reducing energy demand by partially milking cows decreased blood BHB concentrations and the incidence of hyperketonemia compared with completely milked cows (Carbonneau et al., 2012; Morin et al., 2018). In the present study we did not collect blood NEFA and glucose data; however, results of other studies support that reducing MF improves energy status. In short-term early lactation studies, healthy cows milked $1 \times$ had greater blood glucose and lower blood NEFA concentrations than cows milked $2 \times$ (Rémond et al., 2002; Kay et al., 2013; Phyn et al., 2014). Carbonneau et al. (2012) observed the same effect when cows were incompletely milked for the first $5 \mathrm{~d}$ of lactation.

Our results demonstrated that reducing MF from $2 \times$ to $1 \times$ improved ketosis resolution and reduced blood BHB concentrations. However, the implementation of this practice as a ketosis treatment would depend on the balance between reducing the risk of negative effects of ketosis on subsequent disease risk and reproduction versus income from salable milk.

\section{Milk Yield, Components, and Linear Score}

Milking frequency is among several factors that influence milk yield (Collier et al., 2017). The effects of increasing daily MF persist after returning to a lower MF scheme (Bar-Peled et al., 1995; Hale et al., 2003). This phenomenon is explained by an alteration in proliferation of mammary cells and IGF-I signaling secondary to the change in MF (Murney et al., 2015). While most of MF studies are focused on the effects of increasing daily MF on milk production, particularly in early lactation, our study aimed to assess the effects of a temporary reduction of MF in ketotic cows.

Upon ketosis detection in early lactation, reduction of MF from $2 \times$ to $1 \times$ decreased milk yield during the $14 \mathrm{~d}$ of reduced MF and in third or greater lactation cows this decrease persisted through 13 wk after return to $2 \times$ milking. The $\sim 25 \%$ reduction in milk yield in our study falls in the 13 to $40 \%$ range reported for shortterm, early lactation studies (O'Driscoll et al., 2012; Stelwagen et al., 2013; Phyn et al., 2014). Following the return to $2 \times$ milking, cows in the ODM group produced $11 \%$ (first-lactation cows) to $17 \%$ ( $\geq$ third-lactation cows) less milk, and 3\% (second-lactation cows) to $25 \%$ ( $\geq$ third-lactation cows) less ECM than cows in the respective TDM treatment group. Cows in the ODM group gradually increased their milk yield and ECM yield but they did not achieve the same yields as TDM cows. The small apparent difference between treatments in projected $305 \mathrm{M}$, across parities, suggests that milk yield might converge over the full lactation, but that requires confirmation with further research. Unfortunately, and because the study was conducted at a research facility, after we finished collecting data, cows enrolled in our study were subsequently included in other nutrition, reproductive, or management trials, which would have interfered with the assessment of treatment in our study on full lactation milk yield. Thus, we were not able to analyze these data.

Researchers who have studied a longer duration of MF reduction (3 to 4-wk) reported long-term milk yield and ECM losses of 6 to $16 \%$ and 5 to $8 \%$, respectively (Schlamberger et al., 2010; Kay et al., 2013; Phyn et al., 2014). Of the few studies that tested $1 \times$ milking for 1 wk, Rémond and Pomiès (2007) reported no difference in long-term milk yield, whereas Loiselle et al. (2009) observed an $8 \%$ decrease in long-term milk yield in the $1 \times$ milking group but similar long-term ECM yield. Additionally, $5 \mathrm{~d}$ of incomplete milking demonstrated no difference in long-term milk yield and ECM yield between milking groups (Carbonneau et al., 2012; Krug et al., 2018).

In our trial, ODM cows had greater milk protein and tended to have greater fat percentage than TDM cows 
over the full 15 wk of observation; these results are consistent with many other short-term $1 \times$ milking trials (Schlamberger et al., 2010; Kay et al., 2013; Phyn et al., 2014).

We observed a tendency for greater LS in the ODM group than in TDM group during and after MF reduction, which was well below the threshold of LS $\geq 4$ (or SCC $\geq 200,000$ ) for subclinical mastitis (Dohoo and Leslie, 1991). Stelwagen et al. (2013) reported consistently elevated LS in cows milked $1 \times$ versus $2 \times$. High-producing cows milked $1 \times$ are more prone to milk leakage (Gleeson et al., 2007; Tucker et al., 2007). Preventing incompletely milked cows from returning to the AMS until the next designated milking may have put some of the ODM cows at a greater risk for milk leakage and increased udder distension during the first 14 DOT. Although these factors may contribute to greater LS in the ODM group, it does not explain why ODM cows had a tendency for greater LS well past the 2-wk reduced MF period. We hypothesize a dilution effect as a potential factor. However, other researchers have examined the long-term effect of a short-term MF reduction on SCC and reported no differences between MF groups after returning to more frequent milking (Loiselle et al., 2009; Schlamberger et al., 2010; Kay et al., 2013). We did not assess behavioral differences between treatment groups, but these changes might have caused frustration in ODM cows related to a restricted access to the AMS of only once per day. Behavioral effects of ODM should be considered in future research.

\section{DMI}

To our surprise, during the treatment period (0 to 14 DOT), cows milked once daily increased DMI at a greater rate than cows milked twice daily, with a significantly greater DMI at d $14(+1.4 \mathrm{~kg} / \mathrm{d})$. Rémond et al. (2004) and Loiselle et al. (2009) reported no difference in DMI between $1 \times$ and $2 \times$ milked cows in early lactation during their experimental periods.

Cows that were milked $2 \times$ produced more milk and maintained a greater BHB blood concentration than cows milked only $1 \times$. A direct effect of blood BHB on DMI could be suggested; however, the effects of blood BHB concentration on appetite suppression remain unclear (Allen, 2014). For example, i.v. administration of different BHB concentrations over $2 \mathrm{~d}$ in 13 mid-lactation multiparous dairy cows did not change DMI (Zarrin et al., 2013). The hepatic oxidation theory (Allen et al., 2009) is a plausible explanation for the greater DMI in cows milked less frequently. The hepatic oxidation theory proposes that feeding behavior depends on liver oxidation and brain signaling (Allen, 2014). Intake suppression in peripartum cows is second- ary to a constant NEFA flux to the liver. Conversely, decreased fuel concentrations in blood stimulate intake due to a greater liver capacity for fuel oxidation (Allen, 2014). This might have been the case in our ODM cows: by reducing MF, ODM cows decreased blood BHB concentrations faster, likely a result of lower circulating NEFA (although not measured) and this would result in signals from the liver stimulating feeding behavior.

Unfortunately, AMS programming errors did not allow us to obtain data during the week following the treatment period (14 to 21 DOT). Ideally, in future MF studies, DMI data should also be collected after the treatment period. This would allow for a better understanding of the relationship between energy demand and intake. Data on liver markers and blood NEFA concentration may be beneficial for the understanding of energy status and liver function dynamics in peripartum cows with different BHB concentrations.

\section{Reproductive Outcomes}

Our study was not designed to measure treatment effects on reproduction, but our data encourage investigation of this in future studies of ketosis therapy. Walsh et al. (2007) observed that cows with increased circulating BHB concentrations had $30 \%$ lower odds of pregnancy at first $\mathrm{AI}$ if $\mathrm{BHB} \geq 1.0 \mathrm{mmol} / \mathrm{L}$ in the first wk of lactation, and $40 \%$ lower odds of pregnancy at first $\mathrm{AI}$ if $\mathrm{BHB} \geq 1.4 \mathrm{mmol} / \mathrm{L}$ in the second week of lactation. Cows exceeding either of those thresholds had a median time to pregnancy 16 to $22 \mathrm{~d}$ longer than cows that never experienced elevated BHB concentrations (Walsh et al., 2007). McArt et al. (2012b) also reported that cows with subclinical ketosis within the first 30 DIM were less likely to conceive at first service. Shortduration reduced MF in early lactation has not been associated with differences in reproductive performance between treatment and control groups (McNamara et al., 2008; Phyn et al., 2014).

\section{Challenges, Limitations, and Considerations for Future Research}

Our sample size is among the limitations of this study. Power calculations (to detect differences in ketosis resolution) indicated a minimum sample of 120 cows for the trial, but fewer cows $(n=104)$ were enrolled due to both time and researcher constraints. However, despite not meeting the estimated sample size, reducing MF was more effective than predicted for resolution of ketosis, so the sample size was adequate to assess our primary outcome.

The sample size calculation did not account for measurement of differences in secondary outcomes of inter- 
est (DMI, milk yield, and reproductive performance). Yet, we were able to detect DMI and milk yield differences between treatment groups. In the future, a substantially larger study size would allow for further inferences about the effect of a $1 \times$ milking strategy applied to ketotic cows on DMI, disease outcomes, reproductive performance, and long-term milk production. A larger study could provide more insights on health outcomes and the balance between the metabolic and possible reproductive benefits versus a detrimental effect on milk production (short and long term).

The excessive AMS pellets allowance in ODM cows for $1 \mathrm{wk}$, after returning to a $2 \times$ milking schedule (a deviation from the study protocol), may have influenced blood BHB concentrations and milk production measured after the 14-d milking frequency treatment period ended, to some degree. Unfortunately, we could not account for this error in our results.

Our study included cows from only one research farm. To our knowledge, this was the first randomized controlled trial to assess the effect of reducing milking frequency as an adjunctive treatment for ketosis. Milking frequency reduction as a treatment should be further tested on multiple commercial farms to increase external validity. Because of the milk yield reduction observed in our trial, dairy producers might be reluctant to test this approach on their farms. However, given the rapid effect of ODM on both reducing ketones and milk yield in this study, subsequent research should assess a shorter duration of MF reduction, perhaps 5 to $7 \mathrm{~d}$. It would also be beneficial to assess MF as a ketosis treatment in herds that milk $3 \times$ (e.g., reduction from to $3 \times$ to $2 \times$ ). If the magnitude of milk yield reduction is not as drastic as observed by reducing from $2 \times$ to $1 \times$ and reproductive performance improves, the implementation of this practice on farm might have a positive cost-benefit result.

Implementation of MF reduction strategy in nonAMS farms might be challenging. An additional pen for ketotic cows could be a potential solution. However, this practice would increase pen movements (regrouping), disrupting social hierarchy and potentially increasing farm labor. Keeping ketotic cows within the same group and bringing them to the parlor (without milking them) would be another option. While this practice could work better in terms of pen management, there could be potential behavioral issues, possibly greater milk leakage, and potential for increased IMI.

\section{CONCLUSIONS}

In this experiment, MF was reduced from 2 milkings per day to 1 milking per day for 2 wk as an adjunct treatment for ketosis. This approach was more successful in resolving ketosis and decreasing BHB concentrations than treating cows with PG alone. Although our findings provide a new approach to treating ketosis in dairy cows, the 2 -wk period of once-daily milking was associated with a substantial reduction in milk yield through the treatment period, and in older cows, for at least 3 mo. Therefore, we encourage future research with a shorter duration of reduced milking frequency and a longer follow-up period to assess effects on milk yield, as well as sufficient numbers of animals to assess reproductive performance.

\section{ACKNOWLEDGMENTS}

Funding for this project was provided by a grant from the Ontario Ministry of Agriculture, Food, and Rural Affairs (Guelph, ON, Canada). Data analysis and preparation of the manuscript were done independently of the project funders. The authors acknowledge the farm staff at the Ontario Dairy Research Centre, University of Guelph for their assistance with the trial. The authors have not stated any conflicts of interest.

\section{REFERENCES}

Allen, M. S. 2014. Drives and limits to feed intake in ruminants. Anim. Prod. Sci. 54:1513-1524. https://doi.org/10.1071/AN14478.

Allen, M. S., B. J. Bradford, and M. Oba. 2009. Board-invited review: The hepatic oxidation theory of the control of feed intake and its application to ruminants. J. Anim. Sci. 87:3317-3334. https://doi .org/10.2527/jas.2009-1779.

Baird, G. D. 1982. Primary ketosis in the high-producing dairy cow: Clinical and subclinical disorders, treatment, prevention, and outlook. J. Dairy Sci. 65:1-10. https://doi.org/10.3168/jds.S0022 -0302(82)82146-2.

Bar-Peled, U., E. Maltz, I. Bruckental, Y. Folman, Y. Kali, H. Gacitua, A. R. Lehrer, C. H. Knight, B. Robinson, H. Voet, and H. Tagari. 1995. Relationship between frequent milking or suckling in early lactation and milk production of high producing dairy cows. J. Dairy Sci. 78:2726-2736. https://doi.org/10.3168/jds.S0022 -0302(95)76903-X.

Bernard, J. K. 1997. Milk production and composition responses to the source of protein supplements in diets containing wheat middlings. J. Dairy Sci. 80:938-942. https://doi.org/10.3168/jds .S0022-0302(97)76017-X.

Capel, M. B., K. D. Bach, S. Mann, and J. A. A. McArt. 2021. A randomized controlled trial to evaluate propylene glycol alone or in combination with dextrose as a treatment for hyperketonemia in dairy cows. J. Dairy Sci. 104:2185-2194. https://doi.org/10.3168/ jds.2020-19111.

Carbonneau, E., A. M. de Passillé, J. Rushen, B. G. Talbot, and P. Lacasse. 2012. The effect of incomplete milking or nursing on milk production, blood metabolites, and immune functions of dairy cows. J. Dairy Sci. 95:6503-6512. https://doi.org/10.3168/jds.2012 $-5643$.

Chapinal, N., D. M. Veira, D. M. Weary, and M. A. G. Von Keyserlingk. 2007. Technical note: Validation of a system for monitoring individual feeding and drinking behavior and intake in group-housed cattle. J. Dairy Sci. 90:5732-5736. https://doi.org/ 10.3168/jds.2007-0331. 
Clark, D. A., C. V. C. Phyn, M. J. Tong, S. J. Collis, and D. E. Dalley. 2006. A systems comparison of once- versus twice-daily milking of pastured dairy cows. J. Dairy Sci. 89:1854-1862. https://doi.org/ 10.3168/jds.S0022-0302(06)72254-8.

Collier, R. J., Y. Xiao, and D. E. Bauman. 2017. Regulation of Factors Affecting Milk Yield. Elsevier Inc.

Couto Serrenho, R. 2021. Reducing milking frequency to treat ketosis - Supplemental Table S1. Mendeley Data, V1. https://doi.org/10 $.17632 / 9 y c r c h b p 6 b .1$.

Dairy Cattle Reproduction Council. 2018. Reproductive Management Strategies for Dairy Cows. Accessed Jun. 30, 2021. https://www .dcrcouncil.org/wp-content/uploads/2018/12/Dairy-Cow-Protocol -Sheet-Updated-2018.pdf.

Davis, S. R., V. C. Farr, and K. Stelwagen. 1999. Regulation of yield loss and milk composition during once-daily milking: A review. Livest. Prod. Sci. 59:77-94. https://doi.org/10.1016/S0301 -6226(98)00204-8.

Dohoo, I. R., and K. E. Leslie. 1991. Evaluation of changes in somatic cell counts as indicators of new intramammary infections. Prev. Vet. Med. 10:225-237. https://doi.org/10.1016/0167 $-5877(91) 90006-\mathrm{N}$.

Duffield, T. 2000. Subclinical ketosis in lactating dairy cattle. Vet. Clin. North Am. Food Anim. Pract. 16:231-253. https://doi.org/ 10.1016/S0749-0720(15)30103-1.

Duffield, T. F., K. D. Lissemore, B. W. McBride, and K. E. Leslie. 2009. Impact of hyperketonemia in early lactation dairy cows on health and production. J. Dairy Sci. 92:571-580. https://doi.org/ 10.3168/jds.2008-1507.

Gleeson, D. E., B. O'Brien, L. Boyle, and B. Earley. 2007. Effect of milking frequency and nutritional level on aspects of the health and welfare of dairy cows. Animal 1:125-132. https://doi.org/10 $.1017 /$ S1751731107658030

Gordon, J. L., S. J. LeBlanc, and T. F. Duffield. 2013. Ketosis treatment in lactating dairy cattle. Vet. Clin. North Am. Food Anim. Pract. 29:433-445. https://doi.org/10.1016/j.cvfa.2013.03.001.

Gordon, J. L., S. J. LeBlanc, D. F. Kelton, T. H. Herdt, L. Neuder, and T. F. Duffield. 2017. Randomized clinical field trial on the effects of butaphosphan-cyanocobalamin and propylene glycol on ketosis resolution and milk production. J. Dairy Sci. 100:3912-3921. https://doi.org/10.3168/jds.2016-11926.

Hale, S. A., A. V. Capuco, and R. A. Erdman. 2003. Milk yield and mammary growth effects due to increased milking frequency during early lactation. J. Dairy Sci. 86:2061-2071. https://doi.org/10 .3168/jds.S0022-0302(03)73795-3.

Herdt, T. H. 2000. Ruminant adaptation to negative energy balance. Influences on the etiology of ketosis and fatty liver. Vet. Clin. North Am. Food Anim. Pract. 16:215-230. https://doi.org/10 .1016/S0749-0720(15)30102-X.

Iwersen, M., U. Falkenberg, R. Voigtsberger, D. Forderung, and W. Heuwieser. 2009. Evaluation of an electronic cowside test to detect subclinical ketosis in dairy cows. J. Dairy Sci. 92:2618-2624. https: //doi.org/10.3168/jds.2008-1795.

Jeong, J. K., I. S. Choi, S. H. Moon, S. C. Lee, H. G. Kang, Y. H. Jung, S. B. Park, and I. H. Kim. 2018. Effect of two treatment protocols for ketosis on the resolution, postpartum health, milk yield, and reproductive outcomes of dairy cows. Theriogenology 106:53-59. https://doi.org/10.1016/j.theriogenology.2017.09.030.

Kay, J. K., C. V. C. Phyn, A. G. Rius, S. R. Morgan, T. M. Grala, and J. R. Roche. 2013. Once-daily milking during a feed deficit decreases milk production but improves energy status in early lactating grazing dairy cows. J. Dairy Sci. 96:6274-6284. https://doi .org/10.3168/jds.2012-6167.

Kelton, D. F., K. D. Lissemore, and R. E. Martin. 1998. Recommendations for recording and calculating the incidence of selected clinical diseases of dairy cattle. J. Dairy Sci. 81:2502-2509. https://doi .org/10.3168/jds.S0022-0302(98)70142-0.

Kiernan, K. 2018. Insights into using the GLIMMIX procedure to model categorical outcomes with random effects. Paper SAS21792018 1-23. https://www.sas.com/content/dam/SAS/support/en/ sas-global-forum-proceedings/2018/2179-2018.pdf.
Kirk, J. H. 1984. Programmable calculator program for linear somatic cell scores to estimate mastitis yield losses. J. Dairy Sci. 67:441443. https://doi.org/10.3168/jds.S0022-0302(84)81322-3.

Krug, C., P. A. Morin, P. Lacasse, D. E. Santschi, J. P. Roy, J. Dubuc, and S. Dufour. 2018. A randomized controlled trial on the effect of incomplete milking during the first 5 days in milk on culling hazard and on milk production and composition of dairy cows. J. Dairy Sci. 101:4367-4377. https://doi.org/10.3168/jds.2017-14021.

LeBlanc, S. 2010. Monitoring metabolic health of dairy cattle in the transition period. J. Reprod. Dev. 56:S29-S35. https://doi.org/10 .1262 /jrd.1056S29.

Loiselle, M. C., C. Ster, B. G. Talbot, X. Zhao, G. F. Wagner, Y. R. Boisclair, and P. Lacasse. 2009. Impact of postpartum milking frequency on the immune system and the blood metabolite concentration of dairy cows. J. Dairy Sci. 92:1900-1912. https://doi.org/ 10.3168/jds.2008-1399.

Mann, S., F. A. L. Yepes, E. Behling-Kelly, and J. A. A. McArt. 2017. The effect of different treatments for early-lactation hyperketonemia on blood $\beta$-hydroxybutyrate, plasma nonesterified fatty acids, glucose, insulin, and glucagon in dairy cattle. J. Dairy Sci 100:6470-6482. https://doi.org/10.3168/jds.2016-12532.

McArt, J. A. A., D. V. Nydam, and G. R. Oetzel. 2012a. Epidemiology of subclinical ketosis in early lactation dairy cattle. J. Dairy Sci. 95:5056-5066. https://doi.org/10.3168/jds.2012-5443.

McArt, J. A. A., D. V. Nydam, and G. R. Oetzel. 2012b. A field trial on the effect of propylene glycol on displaced abomasum, removal from herd, and reproduction in fresh cows diagnosed with subclinical ketosis. J. Dairy Sci. 95:2505-2512. https://doi.org/10.3168/ jds.2011-4908.

McArt, J. A. A., D. V. Nydam, P. A. Ospina, and G. R. Oetzel. 2011. A field trial on the effect of propylene glycol on milk yield and resolution of ketosis in fresh cows diagnosed with subclinical ketosis. J. Dairy Sci. 94:6011-6020. https://doi.org/10.3168/jds.2011 $-4463$.

McNamara, S., J. J. Murphy, F. P. O'Mara, M. Rath, and J. F. Mee. 2008. Effect of milking frequency in early lactation on energy metabolism, milk production and reproductive performance of dairy cows. Livest. Sci. 117:70-78. https://doi.org/10.1016/j.livsci.2007 .11 .013 .

Morin, P. A., C. Krug, Y. Chorfi, J. Dubuc, P. Lacasse, J. P. Roy, D. E. Santschi, and S. Dufour. 2018. A randomized controlled trial on the effect of incomplete milking during early lactation on ketonemia and body condition loss in Holstein dairy cows. J. Dairy Sci. 101:4513-4526. https://doi.org/10.3168/jds.2017-13151.

Murney, R., K. Stelwagen, T. T. Wheeler, J. K. Margerison, and K. Singh. 2015. The effects of milking frequency on insulin-like growth factor I signaling within the mammary gland of dairy cows. J. Dairy Sci. 98:5422-5428. https://doi.org/10.3168/jds.2015-9425.

O'Driscoll, K., G. Olmos, S. Llamas Moya, J. F. Mee, B. Earley, D. Gleeson, B. O'Brien, and L. Boyle. 2012. A reduction in milking frequency and feed allowance improves dairy cow immune status. J. Dairy Sci. 95:1177-1187. https://doi.org/10.3168/jds.2011-4408.

Oetzel, G. R. 2004. Monitoring and testing dairy herds for metabolic disease. Vet. Clin. North Am. Food Anim. Pract. 20:651-674. https://doi.org/10.1016/j.cvfa.2004.06.006.

Phyn, C. V. C., J. K. Kay, A. G. Rius, S. R. Morgan, C. G. Roach, T. M. Grala, and J. R. Roche. 2014. Temporary alterations to postpartum milking frequency affect whole-lactation milk production and the energy status of pasture-grazed dairy cows. J. Dairy Sci. 97:6850-6868. https://doi.org/10.3168/jds.2013-7836.

Rémond, B., S. Aubailly, Y. Chilliard, D. Dupont, D. Pomiès, and M. Petit. 2002. Combined effects of once-daily milking and feeding level in the first three weeks of lactation on milk production and enzyme activities, and nutritional status, in Holstein cows. Anim. Res. 51:101-117. https://doi.org/10.1051/animres:2002014.

Rémond, B., and D. Pomiès. 2007. Once-daily milking of Holstein cows for one-week decreases milk yield by twenty-five percent without any carry-over effect. Livest. Sci. 110:192-195. https://doi.org/10 $.1016 /$ j.livsci.2006.12.009. 
Rémond, B., D. Pomiès, D. Dupont, and Y. Chilliard. 2004. Oncea-day milking of multiparous Holstein cows throughout the entire lactation: Milk yield and composition, and nutritional status. Anim. Res. 53:201-212. https://doi.org/10.1051/animres:2004014.

Sargeant, J. M., A. M. O'Connor, I. A. Gardner, J. S. Dickson, and M. E. Torrence. 2010. The REFLECT statement: Reporting guidelines for randomized controlled trials in livestock and food safety: Explanation and elaboration. J. Food Prot. 73:579-603. https:// doi.org/10.4315/0362-028X-73.3.579.

Schlamberger, G., S. Wiedemann, E. Viturro, H. H. D. Meyer, and M. Kaske. 2010. Effects of continuous milking during the dry period or once daily milking in the first 4 weeks of lactation on metabolism and productivity of dairy cows. J. Dairy Sci. 93:2471-2485. https://doi.org/10.3168/jds.2009-2823.

Stelwagen, K., C. V. C. Phyn, S. R. Davis, J. Guinard-Flament, D Pomiès, J. R. Roche, and J. K. Kay. 2013. Invited review: Reduced milking frequency: Milk production and management implications. J. Dairy Sci. 96:3401-3413. https://doi.org/10.3168/jds.2012-6074.

Tucker, C. B., D. E. Dalley, J. L. K. Burke, and D. A. Clark. 2007. Milking cows once daily influences behavior and udder firmness at peak and mid lactation. J. Dairy Sci. 90:1692-1703. https://doi .org/10.3168/jds.2006-577.

Voyvoda, H., and H. Erdogan. 2010. Use of a hand-held meter for detecting subclinical ketosis in dairy cows. Res. Vet. Sci. 89:344-351. https://doi.org/10.1016/j.rvsc.2010.04.007.
Walsh, R. B., J. S. Walton, D. F. Kelton, S. J. LeBlanc, K. E. Leslie, and T. F. Duffield. 2007. The effect of subclinical ketosis in early lactation on reproductive performance of postpartum dairy cows. J. Dairy Sci. 90:2788-2796. https://doi.org/10.3168/jds.2006-560.

Zarrin, M., L. De Matteis, M. C. M. B. Vernay, O. Wellnitz, H. A van Dorland, and R. M. Bruckmaier. 2013. Long-term elevation of $\beta$-hydroxybutyrate in dairy cows through infusion: Effects on feed intake, milk production, and metabolism. J. Dairy Sci. 96:29602972. https://doi.org/10.3168/jds.2012-6224.

\section{ORCIDS}

M. Williamson (1) https://orcid.org/0000-0002-8980-8123

R. Couto Serrenho () https://orcid.org/0000-0002-7956-7039

B. W. McBride $\odot$ https://orcid.org/0000-0002-4211-5362

S. J. LeBlanc $\odot$ https://orcid.org/0000-0003-2027-7704

T. J. DeVries (ㄴ) https://orcid.org/0000-0001-9364-2456

T. F. Duffield ๑ https://orcid.org/0000-0001-6035-4669 